\title{
Utilization of Balakka Fruit (Phyllanthus emblica) in Rimba Soping Village, Padangsidimpuan District Angkola Julu
}

\author{
Mukhlis $^{\left.1^{*}\right)}$, Rafiqah Amanda Lubis ${ }^{1}$, Muhammad Agung Permadi ${ }^{1}$, Sulaiman Abdi ${ }^{2}$ \\ ${ }^{1)}$ Faculty of Agriculture, Universitas Muhammadiyah Tapanui Selatan, Padangsidimpuan, 22716 \\ ${ }^{2)}$ Agriculture Instructure of Padang Sidempuan City Government
}

\begin{abstract}
Balakka (Phyllanthus emblica) is specific fruit in Padang Sidempuan, and it has astrigent taste, so that its utilization as food product is not optimal yet. This community service activity was aimed to give the training to the society about balakka fruit processing. The activities include: education about balakka fruit utilization, training of syrup processing from balakka fruit to the women farmer group in Rimba Soping Village, Angkola Julu Regency, Padang Sidempuan city. The results showed that balakka fruit syrup can be accepted by people and has the potential to be developed as a way to increase community income.
\end{abstract}

Keywords: Balakka (Phyllanthus emblica), Innovation, Diversification

\begin{abstract}
Abstrak. Buah balaka (Phyllanthus emblica) adalah buah khas yang terdapat di daerah Padang Sidempuan yang memiliki rasa sepat sehingga pemanfaatannya sebagai produk pangan belum optimal. Kegiatan pengabdian pada masyarakat ini bertujuan untuk memberikan pelatihan kepada masyarakat tentang pengolahan buah balakka. Kegiatan yang dilakukan meliputi: penyuluhan tentang manfaat buah balaka dan pelatihan pembuatan sirup buah balakka kepada kelompok petani wanita di Desa Rimba Soping, Kecamatan Angkola Julu, Kota Padang Sidempuan. Hasil kegiatan menunjukkan sirup buah balakka dapat diterima oleh masyarakat dan berpotensi dikembangkan sebagai salah satu cara untuk meningkatkan pendapatan masyarakat.
\end{abstract}

Kata Kunci: Balakka (Phyllanthus emblica), Inovasi, Diversifikasi

Received 22 November 2018 | Revised 15 March 2019 | Accepted 10 April 2019

\section{Introduction}

Balakka (Phyllanthus emblica) is one of the agricultural commodities found in the Padangsidimpuan area. The hallmark of this balakka plant is its astringent taste, and this

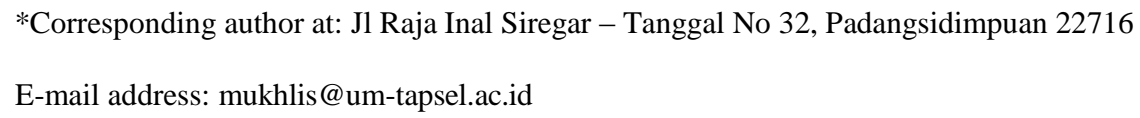


causes it does not have economic value for the people of Padangsidimpuan City, so that these plants are not cultivated optimally. Besides the good taste, the fruits have many benefits or efficacy for human health. The balakka fruits contains high sources of vitamin $\mathrm{C}$ [1], amino acids and minerals [2], and also functions as an antioxidant [3].

Rimba Soping Village, Angkola Julu District is approximately $1.5 \mathrm{~km}$ from Muhammadiyah South Tapanuli University. From the results of the first survey (December 20, 2017), there were 8 farmer groups in the village but only 2 groups were active in doing the farming. One of them is the "Rotama" farmer group, chaired by Ms. Roina Atun, a member of the women farmer group. The group have 32 women farmers, especially housewives who work as farmers. The formation of this group is because they are encouraged to continue farming with the hope of overcoming the family financial problems. The high costs of education, health and basic needs make partners have to work hard to be able to exist in the uncertain economic conditions.

The main technical problems that arise in the village of Rimba Soping is that the farmers do not know the benefits and how to process cash crops optimally. The lack of an important information and appropriate knowledge in food technology often causes the farmers are being reluctant to apply the technology on their business. However, this is quite reasonable because it requires a lot of money and also the risk of failure to adopt and apply the technology.

\section{Method}

Preliminary observation on the members of farmer groups found that the farming business they are doing continues to experience development. However, the partners are still experiencing the ups and downs on their business, so that they need efforts to improve their financial welfare.

These problems are identified as follows:

1. Inadequate knowledge about food processing technology,

2. Limited information about the benefits of functional foods,

3. Lack of financial asset in starting and running their business,

4. The high risk of failure of a business.

Solutions and Targets are offered based on the partner problems are:

- Scientific reports / journals as information on how balakka fruits are processed to produce functional food in the Rimba Soping village,

- Rimba Soping villagers are able to utilize balakka to become functional food,

- Balakka processed products. 
The targeted output is in the form of methods, goods / products.

\section{Implementation Method}

The methods offered to overcome partner problems are:

1. Providing counseling about balakka fruit and its benefits,

2. Providing training for the processing of balakka fruits.

\section{Result and Discussion}

Program Activity on the processing and utilization of balakka fruit (Phyllanthus emblica) in Rimba Soping Village Padangsidimpuan District Angkola Julu was carried out based on the previous plans. The results that have been achieved are as follows:

1. Instruction of the benefits of balakka fruit

Instruction and direction were carried out by a community service team consisting of executive lecturers, students and accompanied by local agricultural extension staff. The activity begins with the reading of the holy verses of the Koran by UMTS agricultural students then followed by opening speech from the chief executive of dedication and the chairman of the Rotama peasant women's group. In his speech the chief executive conveyed the potential of local fruits in the South Tapanuli area which are not well known by the public in general. The explanation on the benefits of balakka fruit was conducted by the students of the Faculty of Agriculture as well as the innovators of the balakka fruit.
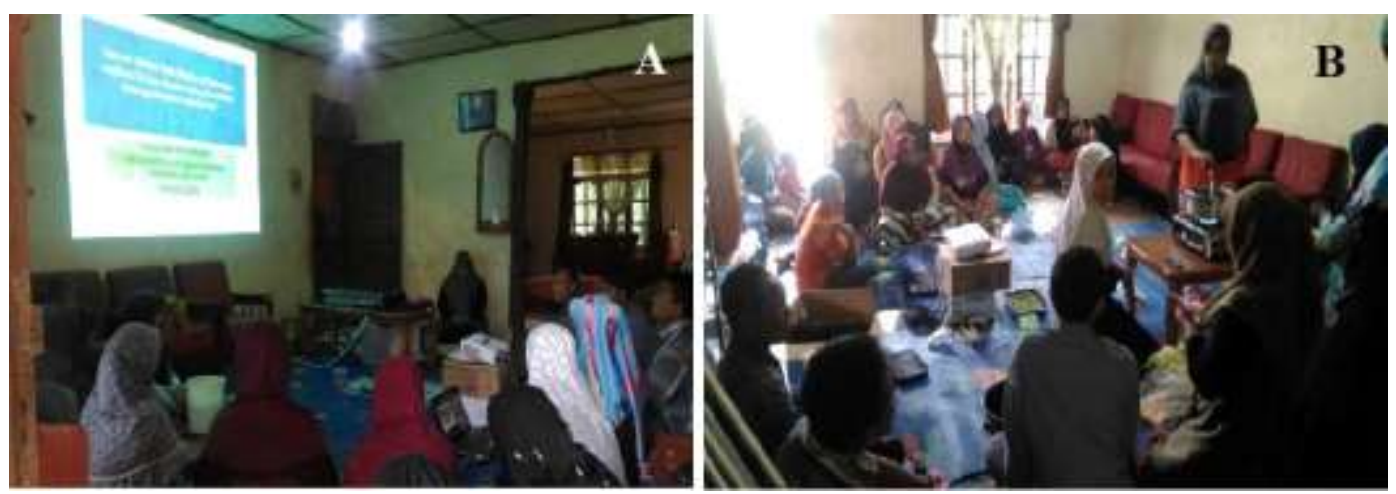

Figure 1. A) Workshop of balakka fruit; B) Training of balakka fruit processing

The participants were very enthusiastic in following the activities as follow in Figure 1. They paid attention to the material presented and asked important questions. The fruit of balakka in this area is easily found, however, it does not get the special attention for the local community due to the unpleasant taste. However, through an innovation of Faculty of Agriculture students, the fruits can finally be diversified into several forms of processed food with added value and even worth selling. 
The group of women farmers in Rimba Soping Village are only relies on the income from farming rice fields and some trading. However, the new innovation on balakka fruits provides more earnings for mothers of women farmer groups in general and Women Farmer Group Rotama in particular, because utilizing local fruits with little innovation can also help the family economy.

2. Training of balakka fruit processing

To ensure that participants understand the material presented, this activity was followed by training and assistance in preparation of balakka fruit before processing. This assistance also aims to enable participants to produce processed fruit and to provide a knowledge on initiating new businesses for interested participants. After completion of this activity, it is expected that the women groups get involved in improving the welfare of the farmers.

\section{Conclusion}

The Community Partnership Program activities is very positive, and the knowledge and informations were given to partners in an effort to use balakka fruit, so that there is added value from balakka fruit. The "Rotama" women farmer group have high motivation to produce innovative balakka fruit product. Reducing financial asset constraints in starting a new business by utilizing available natural products.

\section{References}

[1] Qureshi S. A, Asad W, Sultana, V. 2009. The Effect of Phyllanthus emblica Linn on type- II diabetes, triglycerides and liver- specific enzyme. Pakistan Journal of Nutrition. 8 (2): 125-128.

[2] Krishnaveni M and Mirunalini S. 2010. Therapeutic potential of Phyllanthus emblica (amla): the ayurvedic wonder. Journal Basic Clin Physiol Pharmacol. 21 (1): 93-105.

[3] Charoenteeraboon J, Ngamkitidechakul, Soonthornchareonnon N, Jaijoy K, Eratawong S. S. 2010. Antioxidant Activies of The Standardized Water Extract from Fruit of Phyllanthus emblica Linn. Songklanakarin Journal of Science and Technology. 32 (6): 599-604. 